\title{
Estimating Modulus of Elasticify (MOE) of Particleboards Using Artificial Neural Nefworks to Reduce Quality Measurements and Costs
}

\section{Procjena modula elastičnosti (MOE) iverica uz pomoć umjetnih neuronskih mreža radi smanjenja opsega i troškova kontrole kvalitete}

\author{
Original scientific paper • Izvorni znanstveni rad \\ Received-prispjelo: 4. 9. 2018. \\ Accepted-prihvaćeno: 4. 7. 2019. \\ UDK: $630 * 812.701 ; 630 * 863.21$ \\ https://doi.org/10.5552/drvind.2019.1840
}

\begin{abstract}
There are a large number of costs that enterprises need to bear in order to produce the same product at the same quality for a more affordable price. For this reason, enterprises have to minimize their expenses through a couple of measures in order to offer the same product for a lower price by minimizing these costs. Today, quality control and measurements constitute one of the major cost items of enterprises. In this study, the modulus of elasticity values of particleboards were estimated by using Artificial Neural Networks (ANN) and other mechanical properties of particleboards in order to reduce the measurement costs in particleboard enterprises. In addition to that, the future values of modulus of elasticity were also estimated using the same variables with the purpose of monitoring the state of the process. For this purpose, data regarding the mechanical properties of the boards were randomly collected from the enterprise for three months. The sample size (n) was: 6 and the number of samples (m): 65 and a total of 65 average measurement values were obtained for each mechanical property. As a result of the implementation, the low Mean Absolute Percentage Error (MAPE), Mean Absolute Deviation (MAD) and Mean Squared Error (MSE) performance measures of the model clearly showed that some quality characteristics could easily be estimated by the enterprises without having to make any measurements by ANN.
\end{abstract}

Keywords: estimate, modulus of elasticity, particleboard, ANN

SAŽETAK • Tvrtke u proizvodnji imaju velik broj troškova, a cilj im je proizvesti kvalitetne proizvode po što pristupačnijoj cijeni. Stoga nizom mjera nastoje smanjiti proizvodne troškove, ali ponuditi jednako kvalitetan proizvod po nižoj cijeni. Danas su kontrola i provjera kvalitete jedna od glavnih stavki troškova poduzeća. U ovom su istraživanju procijenjene vrijednosti modula elastičnosti i drugih mehaničkih svojstava iverice primjenom umjetnih neuronskih mreža (ANN) kako bi se smanjili troškovi kontrole kvalitete. Osim toga, uz pomoću istih varijabli procijenjene su buduće vrijednosti modula elastičnosti radi praćenja stanja procesa. S tim ciljem poduzeće je tri mjeseca nasumično prikupljalo podatke o mehaničkim svojstvima ploča. Istraživanje je provedeno na uzorku

\footnotetext{
Authors are researcher and professor at Bartin University, Faculty of Forestry, Department of Forest Industrial Engineering, Bartin, Turkey.

Autori su istraživač i profesor Sveučilišta Bartin, Šumarski fakultet, Zavod za inženjerstvo u šumarstvu, Bartin, Turska.
} 
od šest ploča i za svako mehaničko svojstvo dobiveno je ukupno 65 prosječnih mjernih vrijednosti. Kao rezultat implementacije modela, mjerenja su jasno pokazala da tvrtke mogu lako procijeniti neka obilježja kvalitete iverice uz pomoć niske srednje apsolutne pogreške (MAPE), srednjega apsolutnog odstupanja (MAD) i srednje kvadratne pogreške (MSE), bez bilo kakvih mjerenja.

Ključne riječi: procjena, modul elastičnosti, iverica, ANN

\section{INTRODUCTION}

1. UVOD

In order for the enterprises to operate successfully and efficiently in an increasingly competitive environment and to sustain their existence, their products and services need to outperform their competitors in terms of both price and quality. Enterprises that seek to attract more customers by producing quality products on the one hand, are looking for some ways to reduce the costs of quality on the other hand (Kurt, 2018).

Quality cost management in enterprises is seen as one of the most important aspects of the development of a quality management system (Martinez and Selles, 2015; Glogovac and Flipovic, 2018). The aim of the quality management system is not only to improve quality and fulfil customer requirements, but also to find a way to do it with the lowest costs (Holota et al., 2016).

In quality improvement efforts, knowing the future status of the process and achieving successful results with fewer measurements are crucial in reducing operational costs. Today, there are many statistical methods used for prediction purposes. Artificial Neural Networks (ANN), which is inspired by the working principles of the human brain and which is the result of the transfer of the learning process to computer systems, has become a widely used method for estimation purposes in many fields from finance and marketing sector to various engineering sectors (Kurt et al., 2017).

In the literature, ANN method has been widely applied for prediction purposes. For instance, Balestrino et al. (1994); Chen (1994); Aiken et al. (1995); Haas et al. (1995); Kiartzis et al. (1995); Chiang et al. (1996); Gately (1996); Kariniotakis et al. (1996); Kolehmainen et al. (2001); Ho et al. (2002); Pijanowski et al. (2002); Niska et al. (2004); Elminir et al. (2005); Pindoriya et al. (2008); Asilkan and Irmak (2009); Hadavandi et al. (2010); Sahin et al. (2013); Tiryaki and Hamzacebi (2014); Yildirim et al. (2014); Madhoushi and Daneshvar (2016); Mia and Dhar (2016); Fu et al. (2017); Yucesan et al. (2017); Ozsahin and Murat (2018); Qiu et al. (2018) studied ANN method in a wide variety of fields including production, marketing, finance, stock exchange, agriculture, forestry, food, energy, automotive and aviation industry.

Effective use of ANN for solving non-linear problems and giving reliable results has made the use of this method even more common. ANN is able to reveal unknown and unpredictable relationships and provide their more effective and optimum use. Therefore, ANN has an important place in the quality improvement and development stages.

Nowadays, many types of wood-based panels with different properties, such as particleboards and medium density fiberboards, are produced industrially (Istek et al. 2017). The quality control measures carried out in the production processes of these products are of great importance in terms of quality and customer satisfaction of the final product, and these processes require a certain cost and time. The purpose of this study is to reduce the costs of the measurements, which constitute one of the major expense items of the enterprises, and to estimate the future status of the process. In this context, some data were collected about the mechanical properties of the particleboards for three months and efforts were made to estimate the modulus of elasticity of the boards without making any measurements. ANN was used for the estimation, as it has been commonly and successfully used in recent times.

\subsection{Artificial neural network}

1.1. Umjetna neuronska mreža

An ANN is a soft computing technique for output prediction, classification, data fitting, and model recognizing during complex systems (Taghavifa et al., 2013). ANN are constructed from simple operational elements in a serial form. These elements have been inspired by biological neural elements (Mafakheri et al., 2012)

A typical ANN configuration consists of an input layer, hidden layers and an output layer (Cho et al., 2014). Hidden layer(s) and output layer can consist of one or more neurons, while the input layer feeds the neurons in the hidden layer(s) with input values. Each neuron in the hidden layer(s) is interconnected with all the neurons in the output layer. The number of neurons in each layer depends on the user and the scale of the problem (Tumac, 2016)

The function of the network is described as follows:

$$
Y_{\mathrm{j}}=f\left(\sum_{\mathrm{i}} w_{\mathrm{ij}} x_{\mathrm{ij}}\right)
$$

where $Y_{\mathrm{j}}$ is the output of node $j, f$ is the transfer function, $w_{\mathrm{ij}}$ is the connection weight between node $j$ and node $i$ in the lower layer, $x_{\mathrm{ij}}$ is the input signal from the node $i$ in the lower layer node $j$.

One of the most important features distinguishing ANN from other methods is the fact that it is capable of learning. The learning process is defined as the calculation of the connection weights to provide the best result with the given data. ANN keeps the information it collects during learning as connection weights between nerve cells (Kurt et al., 2017).

\section{MATERIALS AND METHODS 2. MATERIJALI I METODE}

\subsection{Data}

2.1. Podatci

The samples were taken from the enterprise, which operates in three shifts per day, for three months in accordance with the sampling plan determined by 
the enterprise. The boards, from which the samples were taken, were $18 \mathrm{~mm}$ in thickness, $630 \mathrm{~kg} / \mathrm{m}^{3}$ in density and $2100 \mathrm{~mm} \times 2800 \mathrm{~mm}$ in size, and they were produced for internal furniture applications (including furniture) under dry conditions. The sizes and parts of the samples used for the tests were determined in accordance with the TS EN 310 (1993), TS EN 311(2005), TS EN 319 (1999) and TS EN 320 (2011).

For the estimation of the modulus of elasticity averages of the boards, the internal bond strength, surface soundness, screw withdrawal strength and postsanding thickness were used. In the study, MATLAB software was utilized for developing the ANN models and for training and estimating the data. $70 \%$ of the total of 65 samples with the sample size (n) of 6 for each mechanical property was allocated for training, $15 \%$ for validation and $15 \%$ for testing.

\subsection{Network architectures}

\subsection{Struktura mreže}

Multilayer Perceptron (MLP) was used as the most appropriate ANN model for the estimation. The MLP, which is commonly used in the literature, consists of an input layer taking the data from outside, an output layer giving the network output to outside and at least one hidden layer between the two of them (Hamzacebi, 2008; Akcan and Kartal, 2011). The MLPs are networks trained as feed-forward and supervised with full connection between layers (Haykin, 1998; Beale et al., 2010).

The studies conducted showed that the single hidden layer gave successful results at any desired degree of accuracy in nonlinear complex structured function approximations. There is no fixed rule for determining the number of neurons in the hidden layer. In general, keeping the number of hidden neurons low may lead to a learning problem in the network, while keeping the number of hidden neurons high may cause the network to memorize instead of learning. Therefore, 1 to 10 tests were made in order to determine the number of hidden neurons in the models and the best result was found to be 8 .

Since the output neuron is directly connected to the studied problem, it is taken equal to the number of dependent variables to be estimated in estimation problems. Sigmoid activation function, which is mostly used in ANN, was preferred as the activation function.

The structure of the ANN model developed for the modulus of elasticity is shown in Figure 1. The values of post-sanding thickness, internal bond strength, screw withdrawal strength and surface soundness of the boards were used as input variables. The output variable, i.e. the modulus of elasticity, was the variable to be estimated.

After the number of neurons in the layers were determined for the ANN model, dependent and independent variables were normalized to be used in the system. In the normalization process, a linear transformation formula in the range of 0 to 10 , namely MinMax normalization, which is commonly used in the literature, was used as shown by Eq. 2 .

$$
x_{n}=\frac{x_{0}-x_{\min }}{x_{\max }-x_{\min }}
$$

After the normalization process, the data was transferred to the program, and training of the network, one of the most important steps, was commenced. At this stage, the data was presented to the network and the network was ensured to be trained.

In order for the model to be installed to give the optimum result, 81 different variations between the values of $0.1-0.9$ were tried for each model by keeping the number of epochs at 1000, and efforts were made to determine the most appropriate momentum and learning coefficient values. After the training of the network was completed, test and validation processes were carried out and the estimation process started.

Since the future values of the dependent variables used in the input layer are necessary in the estimation stage, first of all, these values were estimated by ARIMA (Box-Jenkins) method and re-normalized and future quality values were estimated.

\subsection{Performance evaluation}

2.3. Ocjena učinka

Mean Squared Error (MSE), Mean Absolute Deviation $(M A D)$ and Mean Absolute Percentage Error $(M A P E)$ were used as performance criteria in the study,

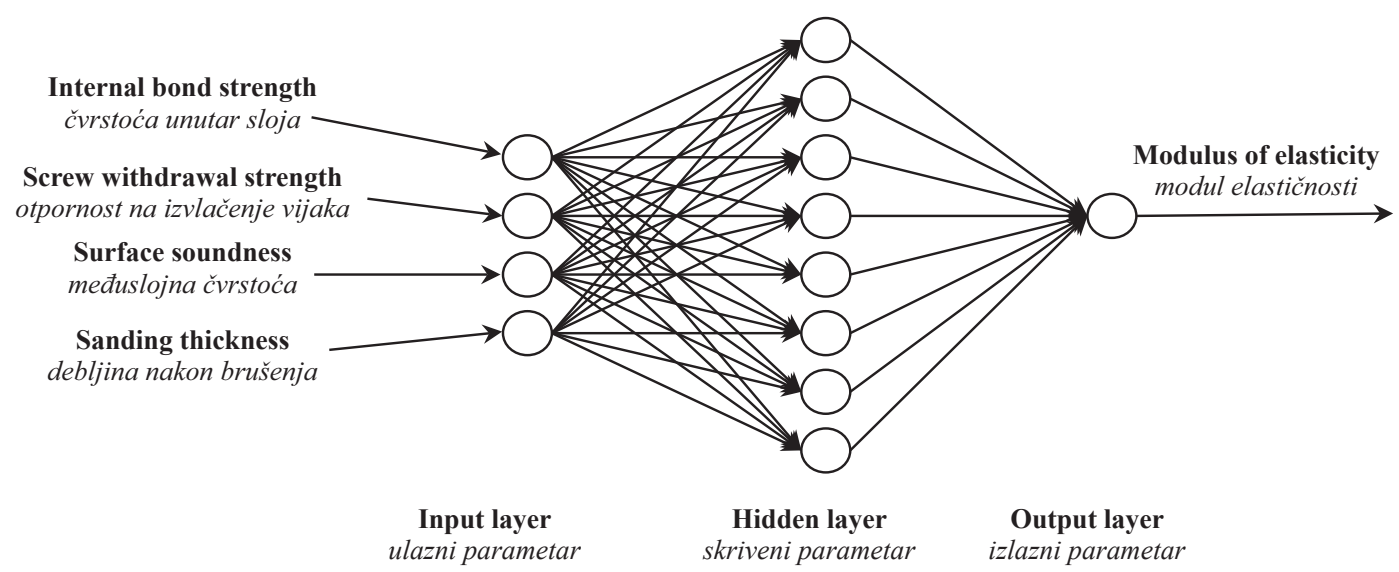

Figure 1 Structure of the ANN model for elasticity module

Slika 1. Struktura ANN-a za modul elastičnosti 
as shown by Eq. 3. Since these are criteria frequently used in the literature and each measure has its own limitations, more than one performance criteria can be used to solve any problem (Gentry et al., 1995).

$$
\begin{gathered}
M S E=\frac{\sum_{i=1}^{n}\left(y_{i}-\hat{y}_{i}\right)}{n} \quad M A D=\frac{\sum_{i=1}^{n}\left|y_{i}-\hat{y}_{i}\right|}{n} \\
M A P E=\frac{\sum_{i=1}^{n} \frac{\left|y_{i}-\hat{y}_{i}\right|}{y_{i}}}{n} \cdot 100
\end{gathered}
$$

where, $y_{\mathrm{i}}$ is the actual observation values, $\hat{y}_{i}$ the estimated values, and $n$ is the number of forecasts.

\section{RESULTS AND DISCUSSION 3 REZULTATI I RASPRAVA}

\subsection{Data analysis, model selection and forecast}

3.1. Analiza podataka, odabir modela i prognoza

Before starting the training of the modulus of elasticity, firstly, the learning and momentum coefficients were tested with different variations and the results were compared. 81 different test results, the MSE values of 5 momentum and learning coefficients giving the best performance are given in Table 1. The most appropriate learning coefficient for the modulus of elasticity was determined as 0.6 and momentum coefficient as 0.8 , respectively.

After the most appropriate parameters for the model were determined, the training of network stage started. The graph showing the change of error values, training status and regression values regarding the training, validation and test sets in each iteration of the modulus of elasticity values as a result of network training is included in Figure 2. The graph shows that over $85 \%$ of the training, validation and test regression values were successful. The best MSE value was obtained as 0.0023615 at the 44 th iteration.

In order to see the training success and estimation ability of the model, the network was tested with test data, which it had never seen before, and successful results were obtained. Table 2 shows the comparison of the estimation values of the test set estimated by the model and the actual values and the error performance criteria MSE, MAD and MAPE. MAD value for modulus of elasticity was found to be 70.89, the $M A P E$ value was found to be 3.022 and the MSE value was found to be 6969.58 . The results show that network training is successful and able to make effective estimations.

After the successful completion of the training, the estimation process started. Figure 3 shows a graphical representation of the actual modulus of elasticity averages and the estimated modulus of elasticity averages used for the test. As it can be seen from the figure, the estimation accuracy of the present average is quite good and some test values are estimated very closely to the actual values. In addition, the graph also shows the change in the future 25 averages of the modulus of elasticity values. The model estimated that there would be a periodic decrease in the estimated values of the modulus of elasticity.

The literature shows that the results of ANN are more successful than other statistical methods. In their study, Gungor et al. (2004), Yucesoy (2011) and Ersen

Table 1 The most appropriate learning and momentum coefficients for the modulus of elasticity ANN model

Tablica 1. Najprikladniji koeficijenti učenja i momenta za modul elastičnosti ANN modela

\begin{tabular}{|c|c|c|c|}
\hline $\begin{array}{c}\text { Trial Number } \\
\text { Broj ponavljanja }\end{array}$ & $\begin{array}{c}\text { Learning rate } \\
\text { Koeficijent učenja }\end{array}$ & $\begin{array}{c}\text { Momentum rate } \\
\text { Koeficijent momenta }\end{array}$ & MSE \\
\hline 19 & 0.3 & 0.1 & 0.00321 \\
\hline 28 & 0.4 & 0.1 & 0.00424 \\
\hline 29 & 0.4 & 0.2 & 0.00367 \\
\hline 44 & 0.5 & 0.8 & 0.00298 \\
\hline 53 & 0.6 & 0.8 & 0.00286 \\
\hline
\end{tabular}

Table 2 Actual and estimated values of modulus of elasticity and their error performances (for test data) $\left(\mathrm{N} / \mathrm{mm}^{2}\right)$ Tablica 2. Stvarne i procijenjene vrijednosti modula elastičnosti i njihove pogreške (za podatke ispitivanja) $\left(\mathrm{N} / \mathrm{mm}^{2}\right)$

\begin{tabular}{|c|c|c|c|c|c|}
\hline $\begin{array}{c}\text { Sample } \\
\text { Uzorak }\end{array}$ & $\begin{array}{c}\text { Actual values } \\
\text { Stvarna vrijednost }\end{array}$ & $\begin{array}{c}\text { Projected values } \\
\text { Procijenjena } \\
\text { vrijednost }\end{array}$ & MAD & MAPE & MSE \\
\hline 56 & 2411.83 & 2496.9161 & 85.08274 & 3.527721 & 7239.073 \\
\hline 57 & 2337.66 & 2407.9113 & 70.24465 & 3.004904 & 4934.311 \\
\hline 58 & 2508.16 & 2458.7836 & 49.38302 & 1.968889 & 2438.683 \\
\hline 59 & 2262.30 & 2298.7184 & 36.38505 & 1.608298 & 1323.872 \\
\hline 60 & 2542.50 & 2504.2217 & 38.27826 & 1.505536 & 1465.225 \\
\hline 61 & 2253.50 & 2435.5461 & 182.0461 & 8.078371 & 33140.780 \\
\hline 62 & 2387.00 & 2499.2648 & 112.2648 & 4.703176 & 12603.390 \\
\hline 63 & 2387.00 & 2439.8620 & 52.86204 & 2.214581 & 2794.395 \\
\hline 64 & 2232,83 & 2287.4963 & 54.66296 & 2.448143 & 2988.039 \\
\hline 65 & 2398.16 & 2370.4538 & 27.71284 & 1.155584 & 768.0014 \\
\hline & & & 70.8922 & 3.02152 & 6969.58 \\
\hline
\end{tabular}



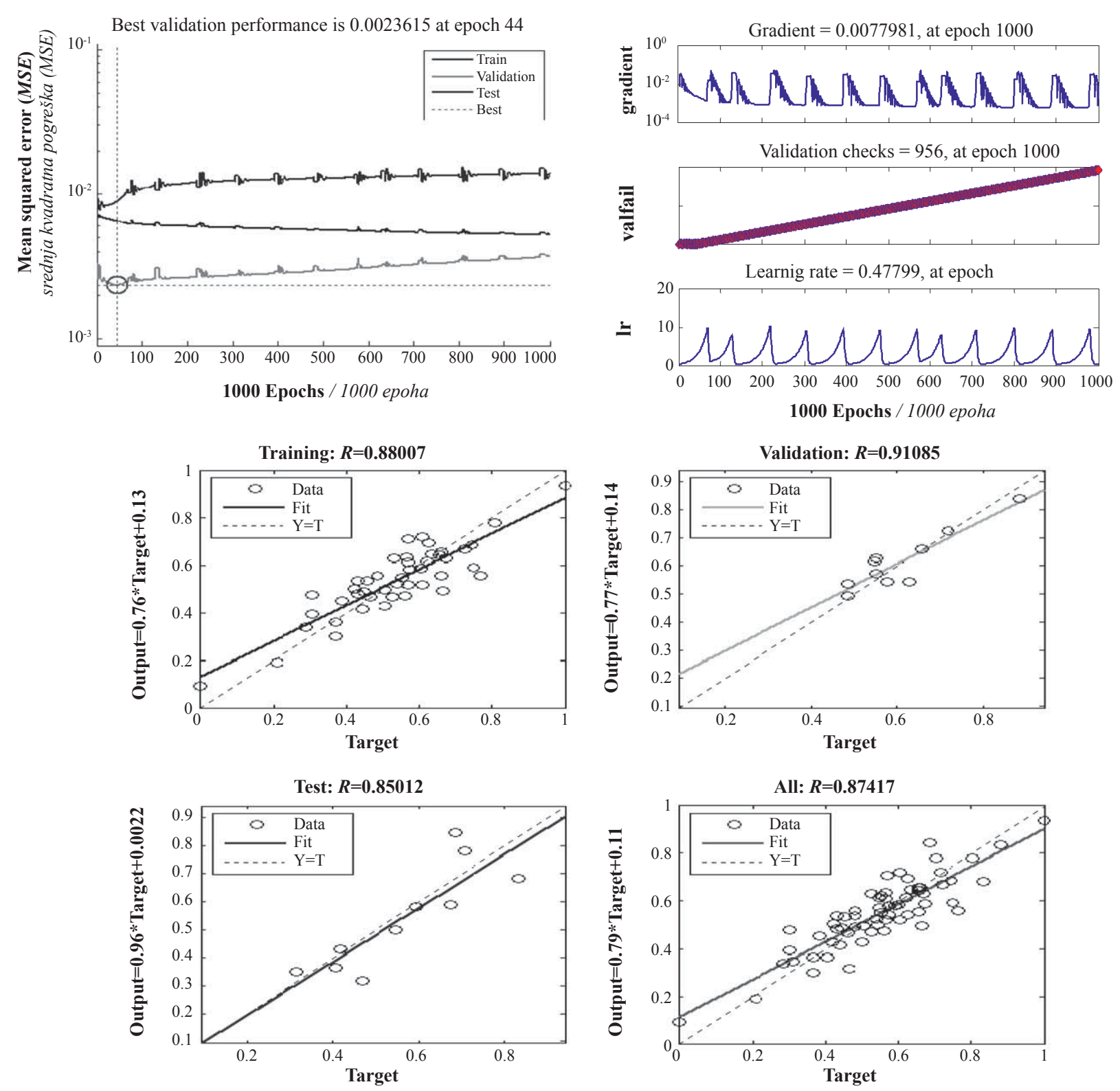

Figure 2 Performance results for the modulus of elasticity ANN model

Slika 2. Rezultati ANN modela za modul elastičnosti

(2016) compared the ANN with different estimation methods such as Moving Averages, Exponential Smoothing, Simple-Multiple Regression, Box Jenkins, and they found that ANN method gives better estima- tion results than other methods. Also, using ANN, Cook and Shannon (1992) have accurately and successfully predicted the parameters of the composite panel production process (about $70 \%$ ).

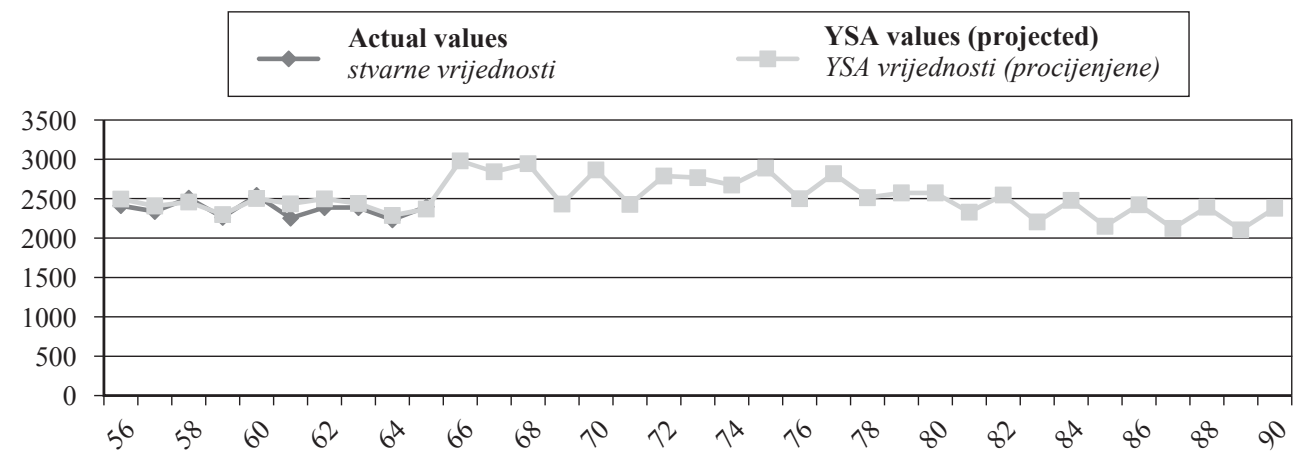

Figure 3 Modulus of elasticity ANN estimation graph $\left(\mathrm{N} / \mathrm{mm}^{2}\right)$

Slika 3. Procijenjeni ANN graf modula elastičnosti $\left(\mathrm{N} / \mathrm{mm}^{2}\right)$ 


\section{CONCLUSIONS}

\section{ZAKLJUČAK}

The most appropriate learning coefficient in the ANN model developed to estimate the modulus of elasticity was determined as 0.6 and momentum coefficient as 0.8 . It is seen that the regression values of the model in training, testing and validation stages are above $85 \%$. When the values estimated by the model and the performance results of the actual modulus of elasticity were examined, the $M S E$ value was found to be 6969.58 , the $M A P E$ value was found to be $3.022 \%$ and the $M A D$ value was found to be 70.89 . It is seen that the performance values obtained are very successful, sufficient and usable for the enterprise. Likewise, in the literature, the models with MAPE values below $10 \%$ are classified as "very good" (Lewis, 1982; Witt and Witt, 1992). Moreover, as it can be seen in Figure 3, the actual and estimated values for the modulus of elasticity are very close to each other. Also, in the estimation of future values of modulus of elasticity, it was determined that the method used in estimating the input variables (ARIMA) was effective and that the results varied according to the performance of the method used.

In general, the use of other mechanical properties as input variables in order to estimate the values of the modulus of elasticity and the fact that it gave successful outcomes showed that some quality values in the enterprises can also be estimated without making any measurements. This is extremely important in terms of reducing the measurement costs of the enterprise. Besides, the possibility of forecasting the future state of these values with ANN shall also enable the enterprise to take precautions against possible problems in advance.

\section{Acknowledgements - Zahvala}

This work was supported by the Bartin University Scientific Research Projects (BAP) (Project Number: 2016-FEN-C-007). The authors would like to thank the Coordinators of Scientific Research Projects of Bartin University.

\section{REFERENCES}

\section{LITERATURA}

1. Aiken, M.; Krosp, J.; Vanjani, M.; Govindarajulu, C.; Sexton, R., 1995: A Neural network for predicting total industrial production. Journal of End User Computing, 7: 19-23.

2. Akcan, A.; Kartal, C., 2011: The forecasting of stock prices in ISE insurance index with artificial neural networks. The Journal of Accounting and Finance, 51: 27-40.

3. Asilkan, O.; Irmak, S., 2009: Forecasting the future prices of the Second-hand automobiles using artificial neural networks. Suleyman Demirel University, The Journal of Faculty of Economics and Administrative Sciences, 14: 375-391.

4. Balestrino, A.; Bini Verona, F.; Santanche, M., 1994: Time series analysis by neural networks: Environmental temperature forecasting. Automazione e Strumentazione, 42: 81-87.

5. Beale, M. H.; Hagan, M. T.; Demuth, H. B., 2010: Neural network toolbox 7 User's guide. The MathWorks Inc., Natick, MA.
6. Chen, C. H., 1994: Neural networks for financial market prediction. In: Proceedings of the IEEE International Conference on Neural Networks, 2: 1199-1202. https://doi.org/10.1109/ICNN.1994.374354.

7. Chiang, W. C.; Urban, T. L.; Baldridge, G. W., 1996: A neural network approach to mutual fund net asset value forecasting. Omega, 24: 205-215. https://doi.org/10.1016/0305-0483(95)00059-3.

8. Cho, S.; Lim, B.; Jung, J.; Kim, S.; Chae, H.; Park, J.; Park, S.; Park, J. K., 2014: Factors affecting algal blooms in a man-made lake and prediction using an artificial neural network. Measurement, 53: 224-233.

https://doi.org/10.1016/j.measurement.2014.03.044.

9. Cook, D. F.; Shannon, R. E., 1992: A predictive neural network modeling system for manufacturing process parameters. International Journal of Production Research, 30 (7): 1537-1550. https://doi.org/10.1080/00207549208948106.

10. Elminir, H. K.; Areed, F. F.; Elsayed, T. S., 2005: Estimation of solar radiation components incident on Helwan site using neural networks. Solar Energy, 79: 270-279. https://doi.org/10.1016/j.solener.2004.11.006.

11. Ersen, N., 2016: The Estimation and Comparison in Turkey's Export and Import Values of Wood and Wood Products with Using Artificial Neural Networks and Box-Jenkins Methods. Ph.D. Thesis, Karadeniz Technical University, Graduate School of Natural and Applied Sciences, Forest Industrial Engineering, 207 pp.

12. Fu, Z.; Avramidis, S.; Zhao, J.; Cai, Y., 2017: Artificial neural network modeling for predicting elastic strain of white birch disks during drying. European Journal of Wood and Wood Products, 75 (6): 949-955. https://doi.org/10.1007/s00107-017-1183-x.

13. Gately, E., 1996: Neural networks for financial forecasting. John Wiley, New York.

14. Gentry, T. W.; Wiliamowski, B. M.; Weatherford, L. R., 1995: A comparison of traditional forecasting techniques and neural networks. Intelligent Engineering Systems Through Artificial Neural Networks, 5: 765-770.

15. Glogovac, M.; Filipovic, J., 2018: Quality costs in practice and an analysis of the factors affecting quality cost management. Total Quality Management and Business Excellence, 29 (13-14): 1521-1544. https://doi.org/10.1080/14783363.2016.1273105.

16. Gungor, I.; Kayacan, C.; Korkmaz, M., 2004: Artificial Neural Networks Use in the Forecasting of Industrial Wood Demand and Comparison with Different Estimation Methods. National Operations Research and Industrial Engineering (ORIE) Congress, Cukurova University, Adana.

17. Haas, D. J.; Milano, J.; Flitter, L., 1995: Prediction of helicopter component loads using neural networks. Journal of the American Helicopter Society, 40: 72-82. https://doi.org/10.4050/JAHS.40.72.

18. Hadavandi, E.; Shavandi, H.; Ghanbari, A., 2010: Integration of genetic fuzzy systems and artificial neural networks for stock price forecasting. Knowledge-Based Systems, 23: 800-808. https://doi.org/10.1016/j.knosys.2010.05.004.

19. Hamzacebi, C., 2008: Improving artificial neural networks: Performance in seasonal time series forecasting. Information Sciences, 178: 4550-4559. https://doi.org/10.1016/j.ins.2008.07.024.

20. Haykin, S., 1998: Neural Networks: A comprehensive foundation, 2 ed. Prentice Hall PTR Upper Saddle River, NJ, USA.

21. Ho, S. L.; Xie, M.; Goh, T. N., 2002: A comperative study of neural network and box-jenkins ARIMA model- 
ing in time series prediction. Computers and Industrial Engineering, 42: 371- 375. https://doi.org/10.1016/S0360-8352(02)00036-0.

22. Holota, T.; Hrubec, J.; Kotus, M.; Holienčinová, M.; Čapošová, E., 2016: The management of quality costs analysis model. Serbian journal of management, 11 (1): 119-127. https://doi.org/10.5937/sjm11-9347.

23. Istek, A.; Ozlusoylu, I.; Kizilkaya, A., 2017: Turkish wood based panel sector analysis. Journal of Bartin Faculty of Forestry, 19 (1): 132-138. https://doi.org/10.24011/barofd.297231.

24. Kariniotakis, G. N.; Stavrakakis, G. S.; Nogaret, E. F., 1996: Wind power forecasting using advanced artificial neural network models. IEEE Transactions on Energy conversion, 11: 762-767.

https://doi.org/10.1109/60.556376.

25. Kiartzis, S. J.; Bakirtzis, A. G.; Petridis, V., 1995: Shortterm load forecasting using neural networks. Electric Power Systems Research, 33: 1-6. https://doi.org/10.1016/0378-7796(95)00920-D.

26. Kolehmainen, M.; Martikainen, H.; Ruuskanen, J., 2001: Neural networks and periodic components used in air quality forecasting. Atmospheric Environment 35: 815825. https://doi.org/10.1016/S1352-2310(00)00385-X.

27. Kurt, R., 2018: Integrated Use of Artificial Neural Networks and Shewhart, CUSUM and EWMA Control Charts in Statistical Process Control: A Case Study in Forest Industry Enterprise. Ph.D. Thesis, Bartin University, Graduate School of Natural and Applied Sciences, Forest Industrial Engineering, 206 pp.

28. Kurt, R.; Karayilmazlar, S.; Cabuk, Y., 2017: Forecasting by using artificial neural networks: Turkey's Paper-paperboard industry case. Journal of Bartin Faculty of Forestry 19:99-106. https://doi.org/10.24011/barofd.334773.

29. Lewis, C. D., 1982: Industrial and business forecasting methods. Butterworths Publishing, London.

30. Madhoushi, M.; Daneshvar, S., 2016: Predicting the static modulus of elasticity in eastern cottonwood (Populus deltoides) using stress wave non-destructive testing in standing trees. European Journal of Wood and Wood Products, 74 (6): 885-892. https://doi.org/10.1007/s00107-016-1043-0.

31. Mafakheri, E.; Tahmasebi, P.; Ghanbari, D., 2012: Application of artificial neural networks for prediction of coercivity of highly ordered cobalt nanowires synthesized by pulse electrodeposition. Measurement 45: 1387-1395. https://doi.org/10.1016/j.measurement.2012.03.027.

32. Martinez, J. M. B.; Selles, M. E. S., 2015: A fuzzy quality cost estimation method. Fuzzy Sets and Systems, 266: 157-170. https://doi.org/10.1016/j.fss.2014.12.014.

33. Mia, M.; Dhar, N. R., 2016: Prediction of surface roughness in hard turning under high pressure coolant using artificial neural network. Measurement, 92: 464-474. https://doi.org/10.1016/j.measurement.2016.06.048.

34. Niska, H.; Hiltunen, T.; Karppinen, A.; Ruuskanen, J.; Kolehmainen, M., 2004: Evolving the neural network model for forecasting air pollution time series. Engineering Applications of Artificial Intelligence, 17: 159-167. https://doi.org/10.1016/j.engappai.2004.02.002.

35. Ozsahin, S.; Murat, M., 2018: Prediction of equilibrium moisture content and specific gravity of heat treated wood by artificial neural networks. European Journal of Wood and Wood Products, 76: 563-572. https://doi.org/10.1007/s00107-017-1219-2.

36. Pijanowski, B. C.; Brown, D. G.; Shellito, B. A.; Manik, G. A., 2002: Using neural networks and GIS to forecast land use changes: A land transformation model. Comput- ers, Environment and Urban Systems, 26: 553-575. https://doi.org/10.1016/S0198-9715(01)00015-1.

37. Pindoriya, N. M.; Singh, S. N.; Singh, S. K., 2008: An adaptive wavelet neural network-based energy, price forecasting in electricity markets. IEEE Transactions On Power Systems, 23: 1423-1432. https://doi.org/10.1109/TPWRS.2008.922251.

38. Qiu, S.; Chen, B.; Wang, R.; Zhu, Z.; Wang, Y.; Qiu, X., 2018: Atmospheric dispersion prediction and source estimation of hazardous gas using artificial neural network, particle swarm optimization and expectation maximization. Atmospheric Environment, 178: 158-163.

https://doi.org/10.1016/j.atmosenv.2018.01.056.

39. Sahin, M.; Buyuktumturk, F.; Oguz, Y., 2013: Light quality control with artificial neural networks. Afyon Kocatepe University Journal of Science and Engineering, 13: 1-10. https://doi.org/10.5578/fmbd.6222.

40. Taghavifa, H.; Mardani, A.; Taghavifar, L., 2013: A hybridized artificial neural network and imperialist competitive algorithm optimization approach for prediction of soil compaction in soil bin facility. Measurement, 46: 2288-2299. https://doi.org/10.1016/j.measurement.2013.04.077.

41. Tiryaki, S.; Hamzacebi, C., 2014: Predicting modulus of rupture (MOR) and modulus of elasticity (MOE) of heat treated woods by artificial neural networks. Measurement, 49: 266-274. https://doi.org/10.1016/j.measurement.2013.12.004.

42. Tumac, D., 2016: Artificial neural network application to predict the sawability performance of large diameter circular saws. Measurement, 80: 12-20. https://doi.org/10.1016/j.measurement.2015.11.025.

43. Yildirim, I.; Ozsahin, S.; Okan, O. T., 2014: Prediction of non-wood forest products trade using artificial neural networks. Journal of Agricultural Science and Technology, 16: 1493-1504.

44. Yucesan, M.; Gul, M.; Erkan, E., 2017: Application of artificial neural networks using Bayesian training rule in sales forecasting for furniture industry. Drvna industrija, 68 (3): 219-228. https://doi.org/10.5552/drind.2017.1706.

45. Yucesoy, M., 2011: Sales Forecasting with Artificial Neural Networks in Tissue Paper Sector. Master Thesis, Istanbul Technical University, Graduate School of Natural and Applied Sciences, Industrial Engineering, $115 \mathrm{pp}$.

46. Witt, S. F.; Witt, C. A., 1992: Modeling and forecasting demand in tourism. Academic Press, Londra.

47. ***TS EN 310: 1993 Wood-Based panels-Determination of modulus of elasticity in bending and of bending strength. Ankara.

48. ***TS EN 311: 2005 Wood-based panels-Surface soundness-Test. Ankara.

49. ***TS EN 319: 1999 Particleboards and fibreboardsDetermination of tensile strength perpendicular to the plane of the board. Ankara.

50. ***TS EN 320: 2011 Fibreboards; determination of resistance to axial withdrawal of screws. Ankara.

\section{Corresponding address:}

\section{RIFAT KURT, Ph.D.}

\section{Bartin University}

Faculty of Forestry

Department of Forest Industrial Engineering

74100 Bartin, TURKEY

e-mail: rkurt@bartin.edu.tr 